\title{
BRACKISH KARST SPRINGS SIMULATION WITH "MODKARST" MODEL UNDER NOT ENOUGH DATA CONDITIONS (THE CASE OF THE “POTAMI” SPRING AT HIMARA ALBANIA)
}

\author{
Maramathas A. ${ }^{1}$, Gialamas J. ${ }^{2}$, Pambuku A. ${ }^{3}$, Beshku H. ${ }^{4}$, Vako E. ${ }^{5}$ \\ ${ }^{1}$ National Technical University of Athens, School of Chemical Engineering, GR 15780 Athens, Greece, \\ thamar@chemeng.ntua.gr \\ ${ }^{2}$ National Center for Marine Research, Agios Kosmas Helliniko, GR-16604, Athens, Greece, jgiala@hcmr.gr \\ ${ }^{3}$ Albanian Geological Survey Rr. Kavajes, Nr.153, Tirana-Albania, urtesi2001@yahoo.com \\ ${ }^{4}$ Albanian Geological Survey Rr. Vasil Shanto, Laboratori i Ujrave, Tirana-Albania \\ ${ }^{5}$ Tirana Polytechnic University, Energy, Water and Environmental Institute \\ Rr. Durresit, Nr. 219, Tirana-Albania
}

\begin{abstract}
A simulation is presented of the operation of a brackish karst spring with the MODKARST deterministic mathematical model under not enough data conditions. MODKARST is a deterministic mathematical model for karst springs, able to accommodate brackish water. It incorporates mass and energy balances in a system of reservoirs properly connected that approximates the karst system and the sea. A complete fitting for this model needs field measurements about spring discharge and spring water chloride concentration at least for a hydrological year. The particular case analysed is the "Potami" brackish karst spring at Himara in Albania. MODKARST simulated the hydrograph along with the variation with time of the chloride concentration. The fitting of the model was based only on chloride concentrations measurements of the spring water that have taken place from 1/5/2007 till 27/12/2007, since there were not spring discharge measurements except for a single one, which simply gave the order of magnitude of this parameter. From the simulation of the model, information was drawn about the recharge area, the effective infiltration coefficient and the dominant seawater intrusion mechanism of the spring. Taking the above information into account, a set of proposals for the sustainable development of the spring was sketched.
\end{abstract}

Key words: brackish karst spring simulation, Modkarst model, Potami spring, Himara, South Albania.

\section{Introduction}

The ground water salinization is an extremely important phenomenon in the countries around the Mediterranean Sea like Greece and Albania. This problem, which decreases the exploitable quantities of ground water in these regions, will get worse in the future due to intensive exploitation and climate changing (planet warming, rainfall diminishing, sea-level upraising). Thus, it is of great importance the development of a methodology in order to predict quantitatively, the salinization phenomenon and support the decision about the method of a sustainable exploitation. Such a methodology does not exist till now and every exploitation effort is based mostly on the empirical trial and error method. 
The objective of this paper is the presentation of a methodology for the quantitative prediction of the salinization phenomenon for the karst ground water that outflows from coastal or submarine springs. The above-mentioned objective was the main goal of an E.C. funded project in the framework of the Greek-Albanian cooperation. As it is known, karst water is the ground water that flows in conduits formed by the erosion, in the carbonate rocks. Karst water is a very important portion of the whole ground water wealth in Greece and also in Albania. The above-mentioned methodology is based on the simulation of the spring using the MODKARST deterministic mathematical model.

For the above-mentioned purpose the "Potami" karst spring at Himara in Albania has been studied. The Albanian team bound itself to take a time series of measurements for the model fitting, that is, spring discharge, spring water chloride measurements and rainfall of the feed area of the spring. The Greek team undertook to simulate the spring using the mathematical model 'MODKARST' (Maramathas et al, 2003) and to suggest the most suitable method for its exploitation.

The main goal was achieved. The spring was satisfactorily simulated and some conclusions arouse about the seawater intrusion mechanism and the proper method for the sustainable development of the spring. The only problem was that the Albanian team did not take quite reliable discharge measurements of the spring since it did not possess the suitable instrumentation for it. Nevertheless, even if there were not such measurements the spring was simulated and in that way it has been proved that MODKARST model could be used even if there are not enough field data. This knowledge was one of the most important conclusions of the project. The above-mentioned innovative methodology of study for the specific spring is recommended for all the brackish karst springs.

In the next paragraphs the research work will be described and the conclusions and suggestions for the continuation of the research will be presented. The continuation of the research will be useful for both of the countries.

\section{The Potami spring}

The Potami spring is located at Himara town (Fig. 1), at southwestern Albania. It is a karst spring that appears along a front by $40 \mathrm{~m}$. Its elevation is $5 \mathrm{~m}$ above the mean sea level and the distance from the seaside of Ionian Sea is about $60 \mathrm{~m}$. The order of magnitude of the spring discharge is $1 \mathrm{~m}^{3} / \mathrm{sec}$ while the chloride concentration of its water presents a small fluctuation during the year getting rates between 350 and $600 \mathrm{ppm}(\mathrm{mg} / \mathrm{l})$. In the sea in front of the spring and at a few hundred meters from the coastline there is fresh water outflow from the bottom that indicates the existence possibly another discharge point of the karst aquifer beyond the spring Potami. Due to limited financing, this point was not studied and was not taken into account for the simulation. However, in the future the relation with the spring must be examined since there is the possibility during the year this point sometimes to operate as submarine spring and sometimes as sinkhole contributing to the salinization of the spring water.

\subsection{Geological structure of the Potami feed area}

Carbonate and terrigenous formations of tectonic zones of Sazani (Pre-Apulian) and Ionian take place in the geological structure of the potami spring feed area (Meço et al., 2005) (Fig. 1).

Sazani zone, where the Potami spring is located (Fig. 2), exists at the most eastern part of the region. In this zone a variety of carbonate depositions were found. They are separated into tectonic blocks because of the strong tectonic activity caused to overthrust of eastern structures. Carbonates lithologically are represented by dolomites of lower Cretaceous $\left(\mathrm{Cr}_{1}\right)$ and dolomitic limestone of upper Cretaceous $\left(\mathrm{Cr}_{2}\right)$. Their thickness varies from 250m to 450m (Meço et al., 2005) (Fig. 2). 


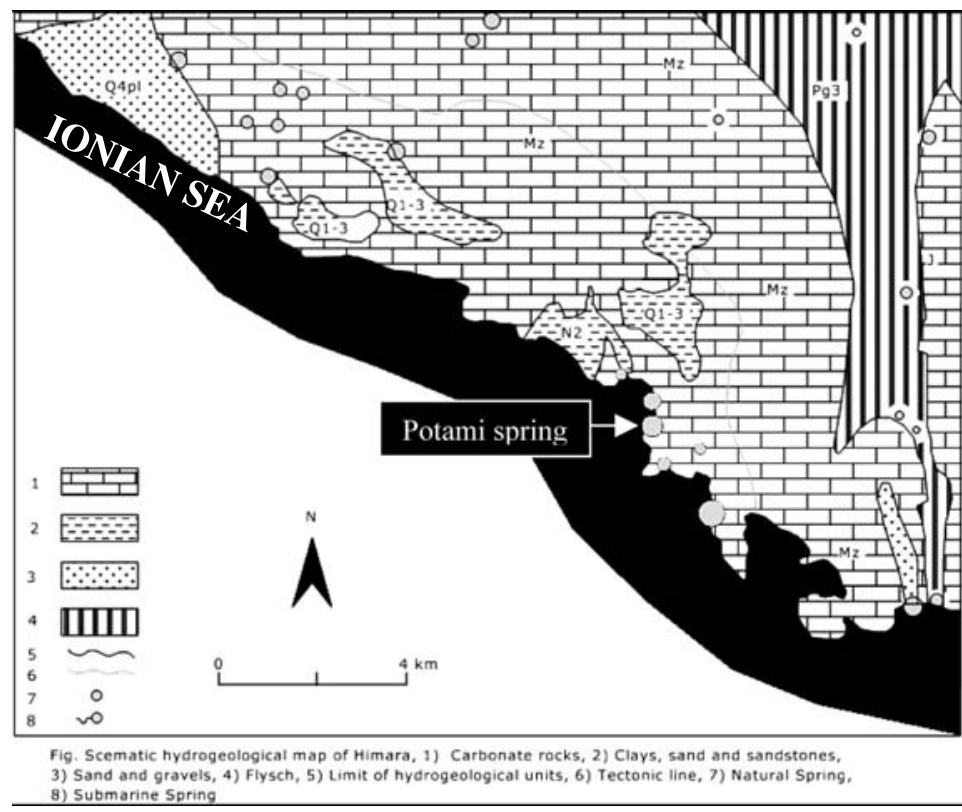

Fig. 1: Schematic hydrogeological map of Himara.

The Ionian zone is represented in the region by the Çika anticline and the Kudhesi Syncline. In Çika anticline there are carbonate depositions of Mesozoic, Paleocene and Eocene which are overthrusted about $10 \mathrm{~km}$ toward the eastern direction. These depositions, lithologically, are represented by diagenetic massive crystalline dolomite and limestone of upper Triassic, dolomite and limestone with flints of upper Jurassic $\left(\mathrm{J}_{1}\right)$, the phase of "Amonitico rosso", thin to medium layers of grey limestone $\left(\mathrm{J}_{1-2}\right)$, micritic, porcelain and argillaceous limestone $\left(\mathrm{Cr}_{1}\right)$ and bio-clastic turbid limestone $\left(\mathrm{Cr}_{2}, \mathrm{Pg}_{1}\right.$, $\mathrm{Pg}_{2}$ ). In this region the thickness of carbonate depositions varies from $1100 \mathrm{~m}$ to $1300 \mathrm{~m}$. In the Kudhesi Syncline there are flysch depositions $\left(\mathrm{Pg}_{3}\right)$, siltstones, clays and sandstones (Meço et al, 2005).

Terrigenous depositions of Neogene $(\mathrm{N})$ have limited spread and are represented by clays and sands with weak cementation (Meço et al., 2005) (Fig. 1).

Quaternary depositions represented by silty clays exist at the centre of the region (Meço et al., 2005).

\subsection{Hydrogeological Conditions}

Ground water is related with the complex of carbonate rocks, which have wide spreading in the area. Karst processes had favourable development conditions particularly in upper Cretaceous and Palaeogene-Eocene carbonates. Carbonate rocks complex has also been affected by the high tectonic and neotectonic activity, which have led to the development of a network of fractures. The above mentioned together with geological-structural favourable composition, have created the conditions for the development of remarkable aquifers (Eftimi et al, 1985; Beshku, 2009).

The rainfall and the snow, which are abundant, particularly in high altitudes, feed these aquifers, while they are discharged by surface and submarine springs. Surface springs (Fig. 1) are numerous, with discharge from $0.051 / \mathrm{s}$ to $6001 / \mathrm{s}$ and spread in the entire area up to the elevation of $1525 \mathrm{~m}$ above the mean sea level. The major springs are situated at the lower sites of the area or closed to seaside. The factors that influence the ground water drainage and the distribution of the springs in the area are 


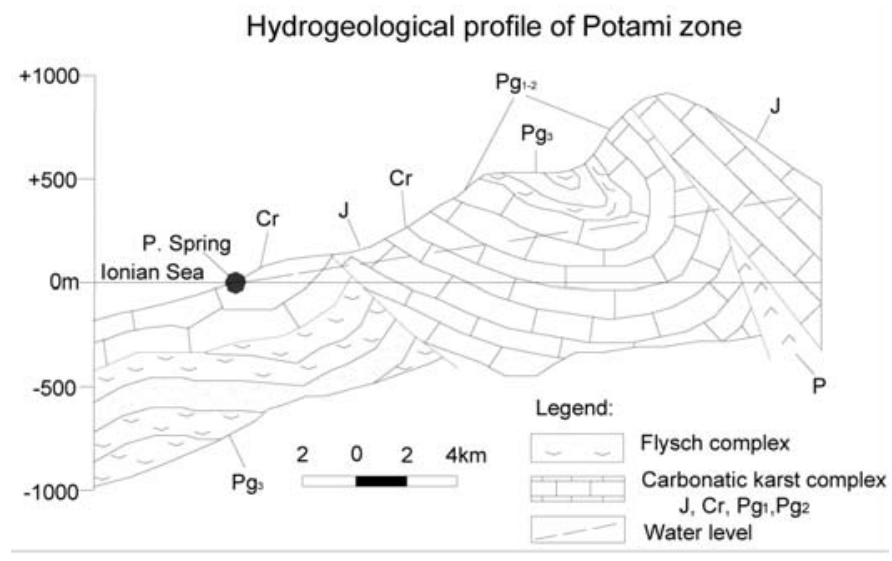

Fig. 2: Hydrogeological profile of Potami spring feed area.

flinty packs, bituminous schist, marls and the tectonics, which controls the presence of the previously mentioned impermeable formations, making impermeable screens. The morphology, characterized by rapid breaks of terrain, is another factor of drainage (Eftimi et al, 1985; Beshku, 2009).

Ground water discharge through submarine springs is favoured from the presence of the karst formations directly under the sea as they are identified at Himara, Porto Palermo and Qeparo (Eftimi et al, 1985; Beshku, 2009).

The potami spring feed area is structured by the formations of the Kudhesi Syncline (carbonate rocks and flysch) separated from the Sazani zone (Pre-Apulian) formations by a fault zone (Eftimi et al, 1985; Beshku, 2009). This fault zone makes an impermeable bar that prevents partially the sea intrusion to the reservoir of the spring (Fig. 2).

\subsection{Chemical composition of ground water}

The chemical composition of ground water is strongly related to lithological-mineralogical composition of carbonate rocks through which circulates and to the seawater intrusion.

The hydrochemical types of ground water that is spread in region are:

Hydrochemical type $\mathbf{H C O}_{3}$-Ca: This type includes groundwater that circulates and appears in springs at high elevation, mainly from flinty limestone of Jurassic age. The water has salinity 0.17 to $0.35 \mathrm{gr} / 1$, total hardness about $12^{\circ} \mathrm{dH}$ and temperature $7^{\circ}-12^{\circ} \mathrm{C}$ (Gjivogli et al 2004).

Hydrochemical type $\mathrm{HCO}_{3}$-Ca-Mg: Includes groundwater from dolomitic limestone and dolomite. This water has salinity 0.25 to $0.4 \mathrm{gr} / 1$, total hardness about $7-14^{\circ} \mathrm{dH}$ and temperature $12-15^{\circ} \mathrm{C}$ (Beshku 2009).

Hydrochemical type $\mathrm{Cl}_{-} \mathrm{HCO}_{3}$-Ca-Mg: Includes the brackish springs, which flow at the seaside from limestone and dolomite as instance Potami and Spile (Himara) springs, some springs in Qeparo, Porto Palermo zone, etc. They are brackish as a result of the mixture of its water with seawater. The water has salinity 1-1.6 gr/l and total hardness about 14-19² $\mathrm{dH}$ (Beshku, 2009).

Hydrochemical type Cl-Na: This type includes the groundwater, which is directly under the seawater influence. The springs which discharge their water almost to sea level belongs to this type (e.g. saline springs of Qeparo) This water has salinity that vary from 6.5 to $7.5 \mathrm{gr} / \mathrm{l}$ and total hardness from 70 to $82^{\circ} \mathrm{dH}$ (Beshku, 2009). 


\section{The MODKARST model}

Fig. 3: Hydrodynamic analogue of a karst spring. The reservoirs "karst 1" and "karst 2" represent the karst subsystems while the other one represents the sea.

MODKARST is a deterministic mathematical model which simulates the hydrograph (discharge versus time) of a karst spring and in case it is brackish the chloride concentration of the spring water versus time. MODKARST model is based on a hydrodynamic analogue of a karst spring that consists of a number of reservoirs properly connected with tubes. One of them emulates the seawater while the others the karst system. Each of these reservoirs is discharged to the tube that abuts to the spring (Fig. 3). Consequently, the spring discharge is given by the sum of these discharges. The chloride concentration of the spring water is determined by the solution of the problem of the mixture between fresh water of the karst reservoirs and salty water of the sea. Rainfall data constitutes the input information to the model, while hydrograph and the chloride concentration of the spring water versus time comprises the output information. The macroscopic mass balance equation and the macroscopic mechanical energy balance equation in a control volume and in the respective control surface have been used in each reservoir to calculate the corresponding discharge. On Table 1 the equations, the variables and the parameters of the model are presented. All the calibration parameters are effective and have a precise physical or geometrical meaning.

For the model fitting the least squares method is used. According to this method, an optimisation program was tasked with estimating the parameter values so that the following mathematical expression

would reach its smallest possible value:

where

are

the model-calculated values for the discharge and chloride concentration,

the field meas-

urements respectively and $\mathrm{D}$ the time period for the optimisation (number of days). A detailed description of the model can be found in the article of Maramathas et al, 2003.

MODKARST model has been used for the simulation of some important Greek brackish karst springs (e.g. Almiros at Heraklion, Crete, Greece) with great success. It can define the seawater intrusion mechanism of a karst spring and it can evaluate the alternative exploitation methods proposing the most suitable for each spring. 
Table 1. Equations - Variables - Parameters of the model.

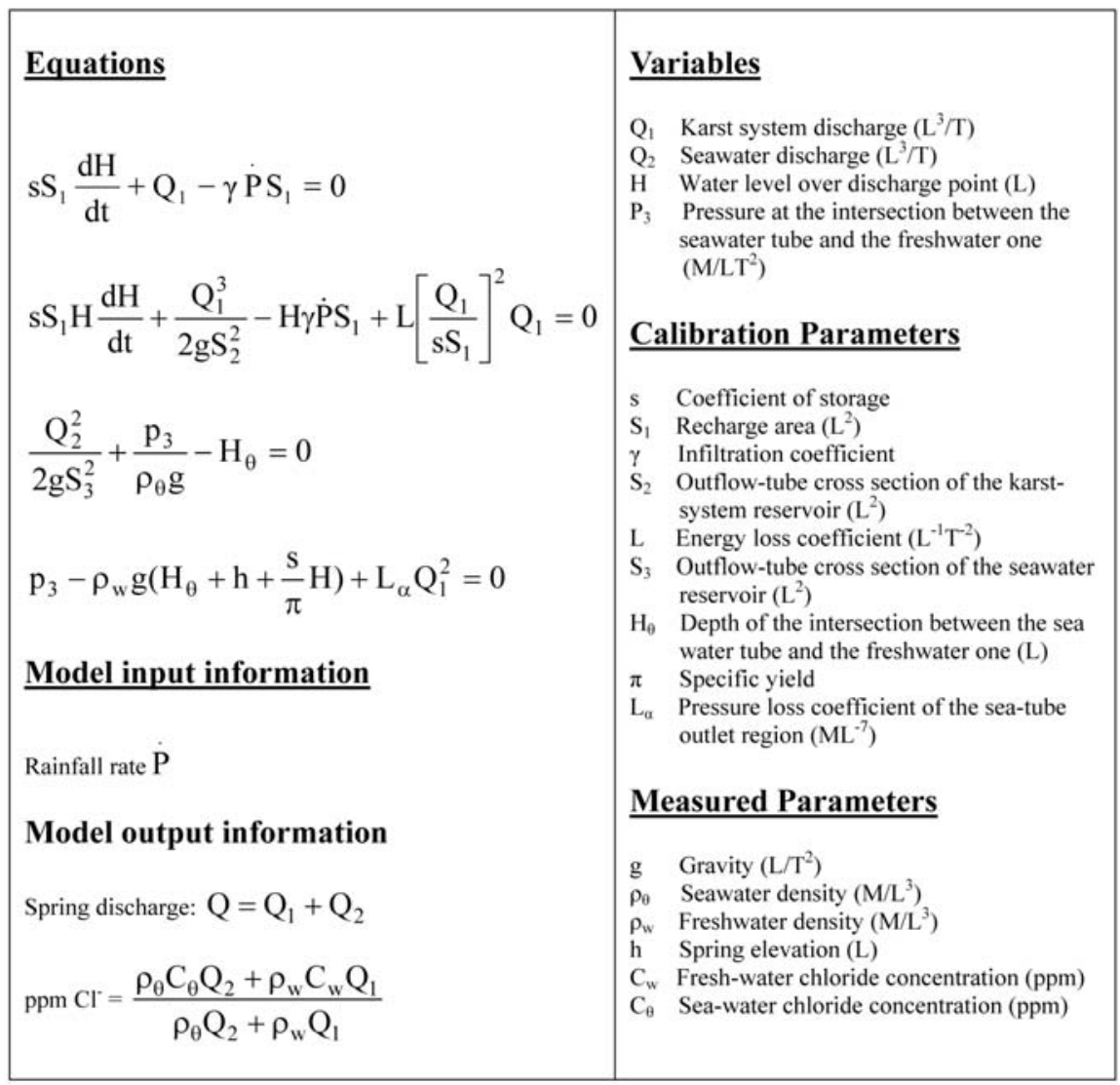

\section{The Potami spring simulation - Results and Discussion}

The Albanian team has taken systematically chloride concentration measurements and rainfall measurements during the second half of 2007. The spring discharge has been measured occasionally by the Albanian team due to lack of proper instrumentation while it has been measured for one time by the Greek team with its own instrument during its visit in the area. Because of this, only the order of magnitude of this parameter (discharge) was available for the model fitting.

Contrary to the lack of discharge measurements, model fitting was successful. The simulation period was from 1/5/2007 until 31/12/2007. The results are shown in figures 4 and 5 where the chloride curve (spring water chloride concentration versus time) and the hydrograph (discharge versus time) respectively, are presented. In fig. 4 there are two curves that is the model-calculated curve (in blue) versus the experimental curve from the field measurements (in red). In Fig. 5 there is not experimental curve due to the lack of field measurements (spring discharge). In both of figures the corresponding rainfall measurements of the spring feed area are presented (column type). From the comparison between the model-calculated values (in blue) and the experimental one (in red) in fig. 4 , is concluded that spring simulation is quite satisfactory. The daily fluctuation of the measured curve that one can observe in this figure does not have any relation with the sea intrusion mechanism. It is a local secondary phenomenon in the vicinity of the spring-water outflow, probably dew 


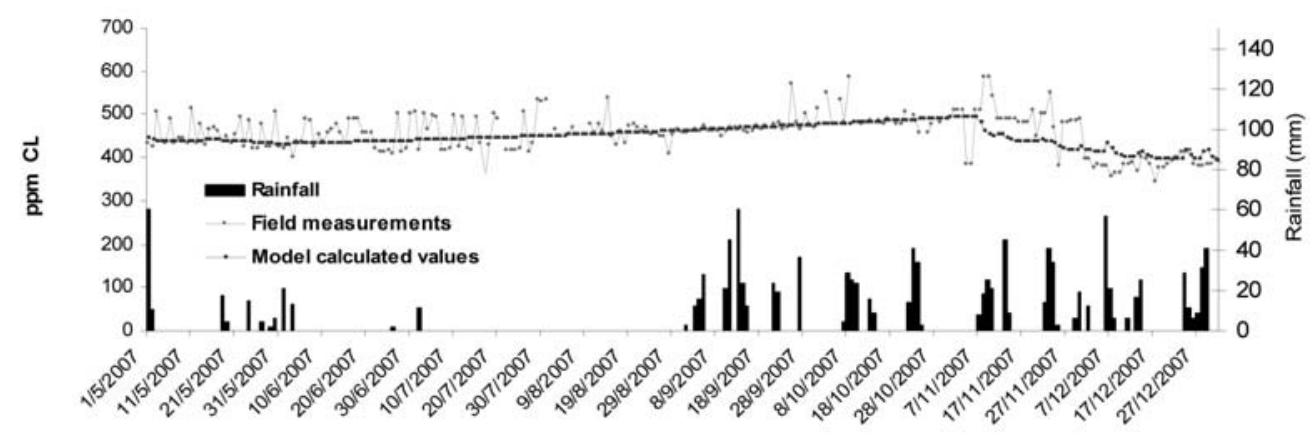

Fig. 4: The chloride concentration curve of the spring.

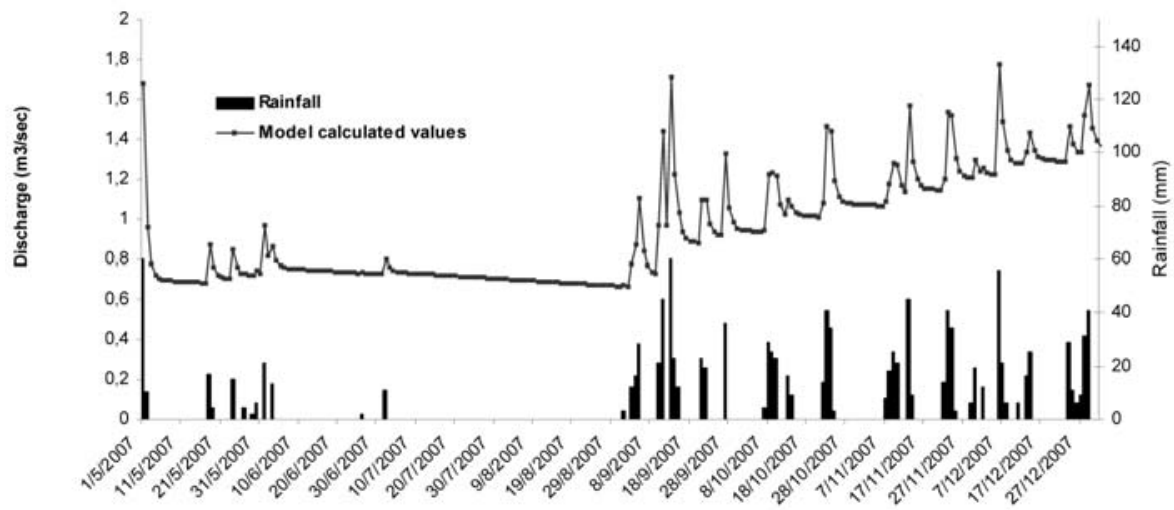

Fig. 5: The Hydrograph of the Potami spring (Discharge versus time).

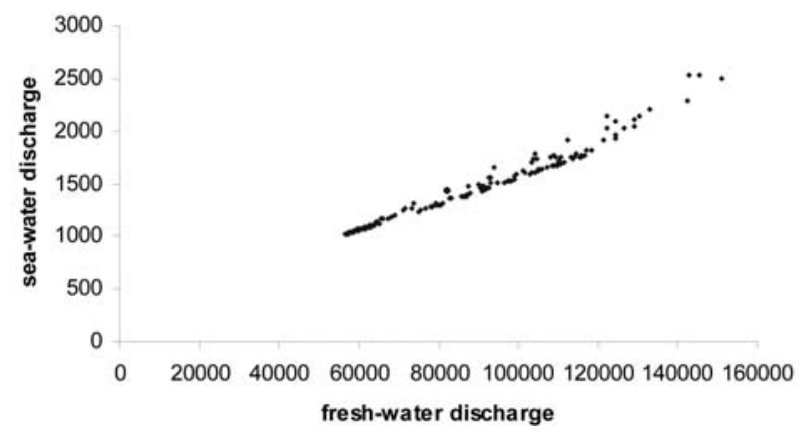

Fig. 6: The seawater discharge increases when the freshwater discharge increases too.

to the tidal fluctuation of the sea level. The chloride concentration simulation is more reliable than the discharge simulation, due to existence of abundant field measurements for the model fitting.

From the spring simulation has been concluded that the dominant seawater intrusion mechanism is the Venturi effect. This conclusion arises since the seawater discharge increases when the freshwater discharge increases too (Fig. 6) (Maramathas et al., 2006). The curve in fig. 6 (seawater dis- 
charge versus freshwater discharge) has been calculated from the model after spring simulation.

Due to the above-mentioned seawater intrusion mechanism some exploitation works are rejected while some others seem to be effective (Maramathas et al, 2006). More specifically, works at the point of spring water outflow that prevent seawater intrusion through the artificial upraising of the karst aquifer piezometric level (e.g. dam construction in front of the spring), do not seem to be effective. On the other hand exploitation works (e.g. drills, tunnels) that could find the freshwater before the point of the seawater intrusion seem to be more efficient. In any case, the relation between the submarine freshwater outflow that mentioned before and the Potami spring must be researched through field study and simulation. If it is proved that the conduits concerned with this submarine freshwater outflow, works reversely some period of the year sending seawater to the aquifer, suitable works could be programmed in order to prevent this operation.

Finally, estimates for some useful parameters of the karst system have been arisen from the simulation. More specifically, the feed area of the spring estimated: $125 \mathrm{~km}^{2}$ while the effective infiltration coefficient estimated: $0.4(40 \%)$.

\section{Conclusions}

1. Model MODKARST can successfully simulates brackish karst springs even if there are not quite enough field measurements for a complete fitting.

2. The dominant sea-water intrusion mechanism for the Potami spring of Himara is the Venturi effect.

3. The feed area of the Potami spring is about $125 \mathrm{~km}^{2}$, while the effective infiltration is $40 \%$.

4. In a first approximation, the suitable method for the development of the spring is a drilling project upstream the salinization point.

\section{References}

Beshku H., 2009, Hydrogeology of Vlora - Saranda Region (in Albanian), PhD Thesis, Archive of National Library, Tirana-Albania.

Eftimi, R., Tafili, I., 1985, Hydrogeological map of Albania at 1:200000, Central Archive of Albanian Geological Survey.

Gjivogli G., Pambuku A., Oruci A., 2004, Water bearing study of coastal line of Vlore-Sarande (in Albanian), Archive of National Library, Tirana-Albania.

Maramathas, A., Pergialiotis, P., Gialamas, I., 2006, Estimation of sea intrusion mechanism of brackish karst springs by their simulation with the "MODKARST" deterministic model. Hydrogeology Journal 14, pp 657-662.

Maramathas, A., Maroulis, Z., Marinos-Kouris, D., 2003, A Brackish Karst Springs Model. Application on Almiros Crete Greece. Ground Water, 41, pp. 608-620.

Meço, S., Onuzi, K., Xhomo, A., 2003, Geological map of Albania at 1:200000, Central Archive of Albanian Geological Survey. 